\title{
The Confidentiality of Criminal Conversations on TDD Relay Systems
}

\author{
Michael F. Kelleher $\dagger$
}

The Americans with Disabilities Act (ADA) provides for a nationwide network to allow users of Telecommunications Devices for the Deaf (TDDs) to communicate with users of voice telephones. Operators will relay calls between TDD and voice telephone users under a statutory requirement that the operator may not reveal the contents of "any" call. This Comment examines the balance between the rights of deaf individuals and the enforcement of criminal law, searching for the proper scope of $A D A$ protection in the statutory language, legislative history, background communication law, and public policy. Each of these sources of statutory interpretation urges that complete confidentiality is necessary to place hearing-and speech-impaired Americans on an equal footing with their fellow citizens. The author argues that relay conversations should be protected by a user-operator privilege and by exclusionary rules preventing the revelation of relay conversations and their fruit in criminal proceedings. Broad privacy protection maximizes the usefulness of the system by allowing relay users to communicate freely and does not impede law enforcement. The author concludes that the mandate of functionally equivalent telecommunications for all can be satisfied only by giving the $A D A$ confidentiality provision its greatest effect.

The passage of the Americans with Disabilities Act (ADA) ${ }^{1}$ in July, 1990 , marked a milestone for the approximately 24 million hearingimpaired and 2.8 million $^{2}$ speech-impaired Americans: improved access to the nation's telephone system. The ADA added section 225 to the Communications Act of $1934 .{ }^{3}$ Section 225 mandated the establishment of a national telecommunications relay system, thereby serving the goal of providing "functionally equivalent" communications to the hearing-

$\dagger$ B.A. 1984, University of Utah; J.D. candidate 1992, Boalt Hall School of Law, University of California, Berkeley. I would like to thank Frank H. Stewart for posing the question this Comment attempts to answer in his presentation to the American Bar Convention on August 6, 1990. I would also like to thank Jocelyn, Arlene Mayerson, Karen Strauss, Professor John Dwyer, Professor Daniel Rodriguez, and the staff of the California Law Review.

1. Americans with Disabilities Act of 1990, Pub. L. No. 101-336, 104 Stat. 327 (to be codified at 42 U.S.C. $\S \S 12,101-12,213,47$ U.S.C. $\S 225$ ).

2. S. ReP. No. 116, 101st Cong., 1st Sess. 77 (1989) [hereinafter Senate Disabilities REPORT]

3. 47 U.S.C. $\S \S 151-613$ (1988). 
and speech-impaired community. ${ }^{4}$

In order to communicate by telephone, hearing- and speechimpaired individuals inust use Telecommunications Devices for the Deaf (TDDs). TDDs are teletype-like devices ${ }^{5}$ that allow a user to type messages to another TDD. The TDD sends electronic pulses to a receiving TDD, which decodes the pulses and displays the message on a screen. The receiving TDD may also print out a transcript. Between 250,000 and 300,000 TDDs are in use around the country, ${ }^{6}$ but TDDs can only communicate with other TDDs. This limitation has denied hearing- and speech-impaired individuals access to inuch of modern society. Isolation from the telecommunications network deprives them of social and economic opportumity. Deaf individuals are not merely hearing impaired, they have become "communication impaired."7

The ADA attempted to bridge gaps "unwillingly created by an insensitive and unsympathetic society." "One way to satisfy the section 225 inandate of functionally equivalent communications is to establish a nationwide relay system that allows TDD users to communicate with individuals who do not have a TDD. ${ }^{9}$ A TDD user calls into the relay service and types to a relay operator's computer terminal. The operator calls the voice user on a separate telephone hine. With both parties on the line, the operator reads the deaf caller's words aloud to the hearing per-

\footnotetext{
4. In order

to make available to all individuals in the United States a rapid, efficient nationwide communications service, ... the [Federal Communications] Commission shall ensure that interstate and intrastate telecommunications relay services are available to the cxtent possible and in the most efficient manner, to hearing-impaired and speech-impaired individuals in the United States.
}

47 U.S.C.A. § 225(b)(1) (West 1991).

"Telecommunication relay services" are defined as

telephone transmission services that provide the ability for an individual who has a hearing impairment or speech impairment to engage in communication by wire or radio with a hearing individual in a manner that is functionally equivalent to the ability of an individual who does not have a hearing impairment or speech impairment to communicate using voice communication services by wire or radio.

Id. $\S 225(\mathrm{a})(3)$ (emphasis added).

5. In addition to dedicated TDDs, computers with modems are able to receive and transmit as a TDD.

6. N.Y. Times, Mar. 30, 1990, at B5, col. 3.

7. Americans with Disabilities Act of 1989: Hearings on S. 933 Before the Subcomm. on the Handicapped of the Senate Comm. on Labor and Human Resources, 101st Cong., 1st Sess. 123 (1989) [hereinafter Senate Disabilities Hearings] (statement of Paul Taylor, Associate Professor, National Technical Institute for the Deaf, Rochester, New York).

8. Americans with Disabilities: Telecommunications Relay Services: Hearing on Title V of H.R. 2273 Before the Subcomm. on Telecommunications and Finance of the House Comm. on Energy and Commerce, 101st Cong., 1st Sess. 1 (1989) [hereinafter House Telecommunications Hearing] (statement of Rep. Markey, subcommittee chairman).

9. 47 U.S.C.A. § $225(\mathrm{a})(3)$ (West 1991) (stating that the term "telecommunications relay services" includes "services that enable two-way communication between an individual who uses a TDD ... and an individual who does not use such a device"). 
son and types the hearing caller's words to the deaf person. The relay operator passes the conversation from one person to the other and occasionally translates the grammar of American Sign Language to English. ${ }^{10}$ Conversely, a hearing caller can conimunicate with a TDD user by first calling the relay operator.

The relay operator's participation in the conversation presents potential confidentiality problems. Accordingly, section 225 "prohibit[s] relay operators from disclosing the content of any relayed conversation and from keeping records of the content of any such conversation beyond the duration of the call." 11 The absolute terms of the confidentiality provision protect the privacy of relay users. Such privacy protection maximizes the usefulness of the system by allowing relay users to communicate freely.

Does the privacy protection, however, extend to criminal conversations, prohibiting the relay operator from disclosing to law-enforcement authorities conversations involving criminal activity? In answering this question, the Federal Communications Commission (FCC) and courts will be called upon to interpret section 225 and the admissibility of criminal relay conversations. ${ }^{12}$ I will attempt to answer the practical question of the statute's proper interpretation. Section 225 is more than just an issue for deaf defendants. Interpreting section 225 also raises the larger question of finding the proper balance between law enforcement and confidentiality. As the newest entry among laws that deal with privilege and exclusion, section 225 deserves careful consideration.

A recent Wisconsin Supreme Court case, State v. Rewolinski, ${ }^{13}$ illustrates the potential conflict between law enforcement and the privacy rights of deaf individuals. Rewolinski, a deaf man, was arrested by the state police for operating a motor vehicle with a suspended driver's hicense. ${ }^{14}$ After being released, Rewolinski used the police station's TDD to call home for a ride. ${ }^{15}$ The TDD printed a transcript of the conversation, which included statenents by Rewolinski's girlfriend that she was afraid of him. ${ }^{16}$ Rewolinski attempted to take the transcript with him,

10. American Sign Language is a language distinct from English and relay operators need to "be able to interpret typewritten American Sign Language and transliterate it to spoken English, and vice versa." 55 Fed. Reg. 50,037, 50,039 (1990) (to be codified at 47 C.F.R. pt. 64) (proposed Dec. 4, 1990).

11. 47 U.S.C.A. $\$ 225(d)(1)(F)$ (West 1991).

12. The FCC believes that all conversations, including criminal conversations, are protected. See 55 Fed. Reg. 50,037, 50,041 (1990) (to be codified at 47 C.F.R. pt. 64) (proposed Dec. 4, 1990) (stating that the FCC's "view is that Congress has mandated that relay operators may not intentionally alter a relayed conversation, no matter what that conversation contains, or reveal its contents").

13. 159 Wis. 2d 1, 464 N.W.2d 401 (1990), cert. denied, 111 S. Ct. 1694 (1991).

14. Id. at 9,464 N.W.2d at 403 .

15. Id. at $9-10,464 \mathrm{~N} . \mathrm{W} .2 \mathrm{~d}$ at 404 .

16. Id. at 11,464 N.W.2d at 404 . 
but a police officer kept it. ${ }^{17}$ After Rewolinski returned home, he strangled his girlfriend. ${ }^{18}$ Over Rewolinski's objections, the TDD transcript was admitted at his trial to prove premeditation. ${ }^{19}$

Discrimination against a deaf man or legitimate evidence? Had Rewolinski used a voice telephone to place his call, the police would not have intercepted his conversation. Rewolinski might then have successfully argued that he strangled his girlfriend in a sudden fit of rage, thereby reducing his crime from murder to manslaughter. On the other hand, Rewolinski did argue with his girlfriend, and the TDD transcript was relevant to show his state of mind. Had the court excluded the TDD transcript, the jury would have rendered a decision based on incomplete facts. Should the court have allowed the prosecutor to prove Rewolinski a murderer with evidence available only because he was deaf? ${ }^{20}$

While the decision in Rewolinski turned on a narrower legal issue, ${ }^{21}$ it frames the broader issue I will address: What balance did the ADA strike between the privacy rights of deaf individuals and the enforcement of criminal law? Answering this question is not easy. While Congress used very broad language in section 225 , prohibiting the disclosure of "any conversation," it did not address the issue of criminal relay conversations in any discussion of the ADA. ${ }^{22}$ Other laws that guarantee privacy by excluding evidence from courts-exclusionary rules and rules of privilege-do so only grudgingly and with frequent exceptions. However, Congress did not express an intent to either incorporate or repudiate these other laws in section 225. Moreover, Congress might have intended to grant greater privacy protection to speech- and hearingimpaired individuals because they must rely on the relay system and because the ADA was crafted as a civil rights provision.

I will interpret section 225 using four sources: text, legislative history, background law, and policy arguments. First, the text of section 225 will be considered. A statute's plain language should be given effect if the text is clear and compatible with the existing laws into which the provision must be integrated. ${ }^{23}$ However, a conflict between section

17. Id. at $10-11,464$ N.W.2d at 404 .

18. Id. at 9,464 N.W. $2 \mathrm{~d}$ at 403 .

19. Id. at 11, 28-31, 464 N.W.2d at 404, 412-13.

20. In this case, the prosecutor could likely have proven Rewolinski guilty of first degree murder without the aid of the TDD transcript. See id. at 27-30, 464 N.W.2d at 411-13 (noting that even if the court had found the transcript to have been illegally seized, Rewolinski's conviction would stand because admission of the transcript would have constituted harmless error). The overriding issue, however, remains the same. Should the state be allowed to prove a crime using evidence it would not have access to if the defendant were not hearing impaired?

21. The Rewolinski court held that the TDD transcript was admissible because Rewolinski did not have a reasonable expectation of privacy. Id. at 6-8, 464 N.W.2d at 402-03.

22. See infra text accompanying notes 27-66.

23. See Eskridge, The New Textualism, 37 UCLA L. REV. 621, 685-86 (1990) (arguing that this plain-meaning rule should be followed by the courts); $c f$. Green v. Bock Laundry Mach. Co., 
225's plain language (protecting the confidentiality of all conversations) and background communications law exists. This is because section 225 arguably changes the default rule that communications workers nuay reveal a criminal conversation inadvertently overheard during the performance of their duties. ${ }^{24}$ Thus, the second part of the analysis will consider the ADA's legislative history. ${ }^{25}$ Unfortunately, the legislative history does not answer the question of proper interpretation. Thus, I will then examine the background law existing before section 225 to resolve the conflict. This background law will be supplemented with a policy analysis. The policy analysis is relevant because a court decision requiring a clearer statement regarding crimmal conversations would be an implicit policy decision. ${ }^{26}$ Such a pohicy decision should be niade with an understanding of earhier decisions that either protected or exposed criminal conversations.

Part I of this Comment will outline the ADA and section 225 in particular. Part II will then turn to the background set of privileges and exclusionary rules that govern similar relationships. Part III will consider the best interpretation of section 225 in light of these earhier laws.

The AMERICANS With Disabilities Act AND SECTION 225

The ADA was a sweeping piece of legislation intended to end discrimination against 43 million individuals with disabilities and to bring them into the economic and social niainstream of American life. ${ }^{27}$ The ADA mandated nondiscrimination and accessibility in employnent, public transportation, public accomnodations, and telecommunications. ${ }^{28}$ In particular, the ADA sought to provide "functionally equivalent" telecommunications service ${ }^{29}$ for the over 24 million hearingimpaired and 2.8 million speech-impaired Americans. ${ }^{30}$

Title IV, section 401(a), of the $\mathrm{ADA}^{31}$ added section 225 to the

490 U.S. 504, 510 (1989) (refusing to apply the plain language of an evidence rule that upset the traditional balance between civil litigants).

24. See infra notes $177-90$ and accompanying text.

25. See infra notes 59-66 and accompanying text.

26. See Eskridge, supra note 23 , at 688-89.

27. Americans with Disablities Act of 1990, Pub. L. No. 101-336, § 2(a)(1), 104 Stat. 327, 328 (1990) (to be codified at 42 U.S.C. $\S 12101$ (a)(1)) (43 million); SENATE DISABILITIES REPORT, supra note 2, at 2 (mainstream).

28. Senate Disabilities Report, supra note 2, at 2-3.

29. 47 U.S.C.A. \& 225(a)(3) (West 1991).

30. Senate Disabil rties RePORT, supra note 2, at 77.

31. Americans with Disabilities Act of 1990 , Pub. L. No. 101-336, § 401(a), 104 Stat. 327, 366 (1990) (to be codified at 47 U.S.C. $\S 225$ ). 
Communications Act of $1934 . .^{32}$ Section 225 requires all telephone companies to provide telecommunication relay services within three years of enactment of the $\mathrm{ADA}^{33}$ and directs the FCC to prescribe regulations for such relay service within one year of the ADA's enactment. ${ }^{34}$ The regulations must: (1) establish relay-service operating guidelines; ${ }^{35}$ (2) establish minimum standards for telephone company provision of relay service; ${ }^{36}$ (3) require relay systems to operate seven days a week, twentyfour hours a day; ${ }^{37}$ (4) require that relay system users pay no more for telecommunications service than comparable nonusers; ${ }^{38}$ (5) prohibit relay operators from refusing calls or limiting the length of calls; ${ }^{39}$ (6) "prohibit relay operators from disclosing the content of any relayed conversation and from keeping records of the content of any such conversation beyond the duration of the call;"40 and (7) "prohibit relay operators from intentionally altering a relayed conversation."41 In formulating these guidelines, the FCC is to solicit and "pay particular attention to input from representatives of the hearing and speech impaired community." $" 42$

The FCC has overall authority to enforce section 225 but may certify states to enforce it intrastate. ${ }^{43}$ The state must show that its program provides relay services in compliance with FCC regulations and has adequate enforcement procedures and remedies. ${ }^{44}$ Complaints under section 225 must be resolved by the FCC or the certified state within 180 days. ${ }^{45}$ Complaints not resolved by a state within 180 days revert to the FCC for enforcement. ${ }^{46}$ The FCC may use the saine remedies, penalties, and procedures in enforcing section 225 with respect to a common carrier as it has in enforcing other provisions of the Communications Act. ${ }^{47}$

32. 47 U.S.C. $\$ \S 151-613$ (1988).

33. 47 U.S.C.A. $\$ 225$ (c) (West 1991).

34. Id. § 225(d). The FCC has issued proposed regulations for comment. See generally 55 Fed. Reg. 50,037 (1990) (proposed Dec. 4, 1990) (to be codified at 47 C.F.R. pts. 0, 32, 36, 64, \& 69).

35. 47 U.S.C.A. § 225(d)(1)(A) (West 1991).

36. Id. $\S 225(\mathrm{~d})(1)(\mathrm{B})$.

37. Id. $\S 225(\mathrm{~d})(1)(\mathrm{C})$.

38. Id. $\S 225(\mathrm{~d})(1)(\mathrm{D})$.

39. Id. $\S 225(\mathrm{~d})(1)(\mathrm{E})$.

40. Id. $\S 225(\mathrm{~d})(1)(\mathrm{F})$.

41. Id. $\S 225(\mathrm{~d})(1)(\mathrm{G})$.

42. Senate Disabilities Report, supra note 2 , at 81 .

43. 47 U.S.C.A. $§ 225$ (e)-(g) (West 1991).

44. Id. $\S 225(\mathrm{I})(1),(2)$.

45. Id. $\S 225(\mathrm{e})(2),(\mathrm{g})(2)(\mathrm{A})$.

46. Id. $\S 225(\mathrm{~g})(2)(\mathrm{A})$.

47. Id. $\S 225(\mathrm{~b})(2)$. A common carrier is defined as "any person engaged as a common carrier for hire, in interstate or foreign communication by wire." 47 U.S.C. $\$ 153($ h) (1988). Section 225 expands the definition of common carrier to include "any common carrier engaged in intrastate communication by wire." 47 U.S.C.A. $\$ 225(a)(1)$ (West 1991). 
The FCC has proposed regulations to implement section 225.48 These regulations do not elaborate on the confidentiality provisions of section 225 , but rather repeat the prohibition of any disclosure. ${ }^{49}$ However, the commentary accompanying the proposed regulations states that the FCC believes that Congress intended to protect even criminal or obscene conversations against disclosure. ${ }^{50}$

\section{A. Statutory Language}

The broad language of the confidentiality provision supports the argument that all conversations are protected. Section 225 provides that an operator must not "disclos[e] the content of any relayed conversation," 51 keep a record of a conversation, ${ }^{52}$ refuse to relay a conversation, ${ }^{53}$ or "intentionally alter[ a relayed conversation." 54 The plain meaning of this section would protect all conversations and guarantee their transmittal, regardless of their content. Moreover, because it prohibits the maintenance of records, section 225 on its face would hinder future evidentiary use of information contained in relay conversations. Thus, when read together, the provisions of section 225 appear to prohibit all disclosure of relayed communications. ${ }^{55}$

Although the statutory language appears to state clearly the intent of section 225, this interpretation arguably conflicts with existing laws that allow disclosure of criminal conversations madvertently overheard by communications workers during the performance of their duties. ${ }^{56}$ Courts may presume that Congress is familiar with the existing legal background and does not intend to change existing laws without explicitly referring to them. ${ }^{57}$ Because section 225 does not exphicitly alter preexisting laws addressing disclosure of criminal conversations, or even

48. See generally 55 Fed. Reg. 50,037 (1990) (to be codified at 47 C.F.R. pts. 0, 32, 36, 64, \& 69) (proposed Dec. 4, 1990).

49. Id. at 50,046.

50. Id. at 50,041 .

51. 47 U.S.C.A. $§ 225(d)(1)(F)$ (West 1991).

52. Id.

53. Id. $\S 225(\mathrm{~d})(1)(\mathrm{E})$.

54. Id. $\S 225(\mathrm{~d})(1)(\mathrm{G})$.

55. Section 225 also requires that the relay service provide deaf and speech-impaired individuals with the ability to communicate using wire and radio in a manner that is "functionally equivalent" to the ability provided to individuals without speech or hearing impairments. Id. $\S 225(a)(3)$. This "functional equivalency" language requires a review of background law to determine the status quo of nonrelay communication. Although the provision is relevant to a consideration of the statute's plain language, consideration of this provision will be postponed until after the background communications laws are explained in Parts II.B.2 \& 3. The meaning of "functional equivalency" is considered further in Part III.A.1.

56. See infra notes $177-90$ and accompanying text.

57. Eskridge, supra note 23, at 634. Eskridge notes, however, that "[1]egislative silence will usually be supporting evidence of legislative intent and will be main evidence only when there is virtually no other evidence of legislative intent." Id. at 640. 
make reference to them, Congress arguably intended to apply section 225 's confidentiality requirement to noncriminal conversations only. ${ }^{58}$

\section{B. Legislative History}

Courts often look to legislative history to confirm or rebut the plain meaming of a statute, or to resolve ambiguity. ${ }^{59}$ Unfortunately, the legislative history of the ADA regarding the intended scope of the relay operator confidentiality requirement is meager. However, the limited consideration of the issue that did take place appears to reinforce a broad interpretation of the provision. For instance, the Senate Report accompanying the ADA states that "the legislation contains provisions to ensure that the privacy of the individuals using the service is protected ... specifically prohibit[ing] relay operators froin disclosing the content of any relayed conversation." 60

Testimony before Senate and House hearings further supports unlimited confidentiality. ${ }^{61}$ At the time Congress was considering the ADA legislation, AT\&T operated TDD relay services in California, New York, and Alabama. ${ }^{62}$ The Califorma Relay Service's policy of total privacy, including nondisclosure of criminal conversations, ${ }^{63}$ is particularly important in considering Congress' intent. Gerald Hines, Director of Special Long Distance Services for AT\&T, testified that his company's relay operators "inust adhere to the highest professional standards of ethics and confidentiality ... [and] relay whatever messages they receive accurately, without passing judgment with respect to their content, conveying communications and not in any way editing or censoring the inessages." 64 Similarly, Merrill Tutton, also of AT\&T, testified that

58. Conversely, Congress' failure to refer to these laws could be interpreted as a rejection of their approach, and thus implies that Congress meant to extend protection to criminal conversations. See infra text accompanying notes 213-14.

59. See Eskridge, supra note 23, at 627, 686 (noting that the Warren and Burger Courts looked to the legislative history of a statute even when the statute's meaning was clear, but concluding that the better rule, which is currently gaining credence, is that "courts should consider legislative history when there are two or more plausible meanings of the provision being interpreted").

60. SEnATE Disabilities RePort, supra note 2, at 89 (emphasis added).

61. Individual testimony during legislative hearings is a relevant factor in interpreting legislation. See Eskridge, supra note 23, at 639-40 ("[T] he testimony of nonlegislative supporters of ... legislation ... [has been] counted as relevant but not critical. . . . The Court will usually invoke these statements as further evidence in support of conclusions gleaned from the statutory text, committee reports, and sponsors' statements.").

62. House Telecommunications Hearing, supra note 8, at 50.

63. California Relay Service Brochure (not dated, on file with the author) ("[California Relay Service] does not try to judge whether a call is either obscene or illegal. Enforcement of such a practice is contrary to an individual caller's right to free speech.").

64. Senate Disabilities Hearings, supra note 7, at 578 (statement of Gerald A. Hines, Director of Special Long Distance Services, AT\&T). 
AT\&T trains relay operators in the "requirement for total privacy." These "privacy issues are utmost of importance," he stated, because the relay operator is uniquely involved in the process of communication. ${ }^{66}$ The operation of these systems, mcluding their privacy policies, provided a model for Congress when it enacted the ADA.

II

\section{Rules of Privilege AND Exclusionary Rules}

The next step in interpreting section 225 is to examine the background law. This is relevant because new laws should be exammed for compatibility with the surrounding body of law. ${ }^{67}$ More importantly, section 225 specifically requires that the relay services provided be "functionally equivalent" to existing communication systems. ${ }^{68}$ Consequently, understanding existing law will be essential to defining "functional equivalency."69

If section 225 is found to preclude evidence of criminal conduct from use by law enforcement, it will not be the first law to do so. Exclusionary rules exclude the use of evidence at trial because the manner in which it was obtained violates the fourth amendment or a statutory prohibition. ${ }^{70}$ Privileges, the rules shielding commnnications between husband and wife, attorney and chent, and physician and patient, exclude evidence in order to foster and protect the underlymg relationships. ${ }^{71}$ The boundaries of privileges and exclusionary rules may sometimes overlap. Both may exclude relevant evidence at trial, thus hindering the courts' trnth-seeking function. ${ }^{72}$

Understanding privileges and exclusionary rules is helpful in interpreting section 225 for a number of reasons. First, section 225 nnight invoke the protection of one of these rules or privileges. ${ }^{73}$ Second, examining this background law will reveal how Congress and the courts have

65. House Telecommunications Hearing, supra note 8, at 52 (statement of Merrill Tutton, VicePresident of Consumer Services, AT\&T).

66. Id.

67. "The meaning of terms on the statute books ought to be determined . . . on the basis of which meaning is (1) most in accord with context and ordinary usage, . . . and (2) most compatible with the surrounding body of law into which the provision must be integrated ...." Green v. Bock Laundry Mach. Co., 490 U.S. 504, 528 (1989) (Scalia, J., concurring).

68. 47 U.S.C.A. $\S 225(a)(3)$ (West 1991).

69. See infra text accompanying notes $206-17$ for a discussion of functional equivalency.

70. See infra text accompanying notes $\mathbf{1 1 5 - 9 0}$ for a discussion of exclusionary rules.

71. See infra text accompanying notes 75-114 for a discussion of privileges.

72. Some exclusionary rules may arguably be considered part of the larger set of "rules of privilege" because they exclude evidence despite its reliability. See MCCORMICK ON EvIDENCE $\S 72$, at 171 (E. Cleary ed., 3d ed. 1984).

73. For example, TDD relay operators would probably fall under the protection of statutes and cases that extend the attorney-client privilege to interpreters. Cf. Gardner, On Guard!, 17 GALlAUdET TODAY 31, 31-33 (1987) (reviewing state laws that protect sign-language interpreters). 
approached and interpreted statutory provisions similar to the ADA's. This understanding will enable a court to interpret section 225 in a manner consistent with Congress' intent. ${ }^{74}$ By understandimg other laws that protect confidential communications, a court can weigh competing policies in the context of section 225. Finally, an examination of privileges and exclusionary rules will demonstrate that the protection of criminal activity is not an implausible imterpretation of section 225 . While protecting criminals may be an undesirable side effect of protecting privacy, such protection is routmely granted in several other situations.

\section{A. Evidentiary Privileges}

\section{Existing Privileges and Their Limits}

Section 225 arguably established a privileged relationship between relay operator and user. Consequently, the rules of privilege that protect other relationships-including those protecting attorney and client, physician and patient, psychotherapist and patient, clergy and penitent, and husband and wife-may provide guidance in interpreting section 225 . Although privileges have their roots in coninion law, most developments in the last century have been legislative. ${ }^{75}$ The reason for this shift probably comes from judicial prejudice against privileges as hindrances to litigation. ${ }^{76}$ The costs to truth seeking of sustaining a privilege are immediate and apparent to courts, whereas the benefits to the privileged relationships accrue outside the courts. ${ }^{77}$ Legislatures have stepped in to balance judicial preference for truth seeking by promoting the competing social value of protecting certain relationships. ${ }^{78}$ In that judicial prejudice against the expansion or creation of privileges may affect the future interpretation of section 225 , judges should recognize that the legislature is often more protective of privacy and should not substitute their judicial policy judgment for the legislature's.

State and federal rules of privilege differ substantially. Most states have codified their rules of privilege, and the substantial acceptance of

74. Cf. Landis, Statutes and the Sources of Law, in HARVARD LEGAL ESSAYS: WRITTEN IN HoNor of AND PRESENTEd to Joseph HeNRY BEALE AND SAMUEL WILliston 213, 214 (1934) (stating that courts should look to underlying statutes as sources for deciding issues beyond the statutes' express scope).

75. See MCCORMICK ON EvidenCE, supra note $72, \S 75$, at 180 (discussing the shift in the development of the rules relating to privileges from the judiciary to the legislature).

76. Id.; see also Saltzburg, Privileges and Professionals: Lawyers and Psychiatrists, 66 VA. L. REv. 597, 599 (1980) (noting that judges "tend to emphasize litigation values at the expense of nonlitigation values protected by evidentiary privileges").

77. See Saltzburg, supra note 76 , at $599-600$ (granting privilege denies specific litigant necessary evidence to avoid a speculative future harm).

78. See MCCORMICK oN EVIDENCE, supra note 72, $\S 75$, at 180 (noting that legislatures are perceived as better able to balance the competing social values because, unlike judges, they are not actively involved in fact-finding). 
the Uniform Rules of Evidence has led to a degree of standardization among state privilege laws. ${ }^{79}$ The federal approach is considerably more schizophrenic. Federal courts look to four separate sources of law: (1) privileges created by federal statute; (2) constitutional privileges; (3) privileges from "common law principles"; and (4) state privilege law in diversity cases. ${ }^{80}$

Section 225 may create a privilege from the first source, a federal statute. Federal statutory privileges bind federal courts in both diversity and federal question cases. ${ }^{81}$ Federal statutory privileges are not uncom1non, ${ }^{82}$ and a statute need not expressly create a privilege but inay instead create one by imphication. For example, in Baldrige v. Shapiro ${ }^{83}$ the Court held that the Census Act created such an impticit privilege against discovery. The Census Act provided that census data should not be disclosed in forms other than tabulations and statistics that did not reveal the information reported by any particular respondent. ${ }^{84}$ The Court held that "this strong policy of nondisclosure [of raw census data] imdicates that Congress intended the confidentiality provisions to constitute a 'privilege' within the meaning of the Federal Rules."85

Statutory privileges can also be implemented and even expanded by administrative regulations. In Whyte v. Connecticut Mutual Life Ins.

79. Note, Developments in the Law: Privileged Communications, 98 HARv. L. REv. 1450, 1462-63 (1985) (showing that the move to make state evidence rules more uniform has met with considerable success).

80. Federal Rule of Evidence 501 in its entirety provides:

Except as otherwise required by the Constitution of the Umited States or provided by Act of Congress or in rules prescribed by the Supreme Court pursuant to statutory authority, the privilege of a witness, person, government, State, or political subdivision thereof shall be governed by the principles of the common law as they may be interpreted by the courts of the United States in the light of reason and experience. However, in civil actions and proceedings, with respect to an element of a claim or defense as to which State law supphies the rule of decision, the privilege of a witness, person, government, State, or political subdivision thereof shall be determined in accordance with State law.

FED. R. Evid. 501.

81. The application of privileges by "Act of Congress" in diversity jurisdiction actions is not clear from the wording of Rule 501, but appears to be the understanding of the rule. See, e.g., Trammel v. United States, 445 U.S. 40, 47 n.8 (1980) (discussing 28 U.S.C. $\S 2076$ and noting that it was enacted so that "state rules of privilege would apply in diversity jurisdiction cases unless Congress authorized otherwise"); FED. R. EVID. 402 advisory committee's note (federal statutes that create privileges are unaffected by the rules of evidence).

82. See, e.g., 13 U.S.C. $\$ 8$ (1988) (making individual responses to census privileged); 13 U.S.C.A. $\$ 9$ (West 1990 \& Supp. 1991) (same); 42 U.S.C. $\$ 2000$ e-5(b) (1988) (making inadmissible into evidence without written consent anything said or done during Equal Employment Opportunity conciliation efforts); 42 U.S.C. $\$ 2240$ (1988) (making required reports of incidents by nuclear facility licensees inadmissible in actions for damages); 45 U.S.C. $\$ \S 33,41$ (1988) (making required railroad accident reports inadmissible as evidence in actions for damages); 49 U.S.C. $\S 1441$ (e) (1988) (making National Transportation Safety Board accident reports inadmissible as evidence in actions for damages).

83. 455 U.S. 345 (1982).

84. Id. at $354-55$.

85. Id. at 361 . 
Co. ${ }^{86}$ a federal statute provided for confidentiality of alcoholism treatment records but authorized their release by court order upon a showing of good cause. The administrative regulation implementing this statute was even more protective of personal patient statements, limiting disclosure to "objective data" only. ${ }^{87}$ In upholding the regulation's ban on discovery, the Whyte court looked to whether the regulations were reasonably related to and furthered the congressional purpose of confidentiality. ${ }^{88}$

Privileges are seldom absolute. Rather, they may be waived either explicitly or implicitly. ${ }^{89}$ Additionally, privileges are often limited with respect to current criminal conversations. For example, the attorneychent privilege protects commumications about past crimes ${ }^{90}$ but does not apply to commumications made for "the purpose of furthering ongoing or future conduct of a crimmal or fraudulent nature."91 Other privileges have similar or stricter limits. For example, some states deny privileges to commumications related to child abuse. ${ }^{92}$ Other states deny any physician-patient privilege to criminal defendants ${ }^{93}$ or affirmatively require a physician to report treatment of certain injuries such as gunshot or knife wounds. ${ }^{94}$ The psychotherapist-patient privilege, at least $\mathrm{m}$ California, has been limited by a requirement to report the confidences of patients who pose an immediate threat to themselves or others. ${ }^{95}$

Distmguishing professional from personal privileges may simplify the task of determining their scope and limitations. ${ }^{96}$ Professional privi-

86. 818 F.2d 1005 (1st Cir. 1987).

87. Id. at 1009.

88. Id. at 1009-10.

89. See, e.g., UTAH CODE ANN. § 78-24-8(2) (Supp. 1990) (attorney may not testify without consent of client); Champion Int'l Corp. v. International Paper Co., 486 F. Supp. 1328, 1332-33 (N.D. Ga. 1980) (finding that voluntary production of privileged documents during discovery, even if inadvertent, can waive privilege, but holding that no waiver occurred). See generally Note, supra note 79, at 1629-65 (discussing various forms of implied waiver).

90. See, e.g., In re Sealed Case, 754 F.2d 395, 402 (D.C. Cir. 1985) (attorney-client communications about past crime remained privileged despite loss of privilege as to attorney-client conversations during ongoing fraud).

91. Note, supra note 79, at 1509-10; see also Nix v. Whiteside, 475 U.S. 157, 167.68 (1986) (discussing exceptions to attorney-client privilege under norms of professional conduct for communications about future crimes).

92. See, e.g., TEX. FAM. CoDE ANN. § 34.04 (Vernon 1986) ("In any proceeding regarding [child neglect or abuse], evidence may not be excluded on the grounds of privileged communication, except in the case of communications between attorney and client.").

93. See, e.g., CAL. Evid. CoDE $\S 998$ (West Supp. 1991); UTAH Code ANN. § 78-24-8(4) (Supp. 1990).

94. See, e.g., Cal. Penal Code $\S 11,161$ (West 1982).

95. See, e.g., Tarasoff v. Regents of the Univ. of Cal., 17 Cal. 3d 425, 433-44, 551 P.2d 334, 342-349, 131 Cal. Rptr. 14, 22-29 (1976) (discussing therapist's liability for failurc to warn victim of patient's threats).

96. See E. Green \& C. Nesson, Problems, Cases, and Materials on Evidence 525-26 (1983) 
lege, such as attorney-client, physician-patient, and clergy-penitent, is only granted to criminal conversations insofar as necessary to defiver the professional service. ${ }^{97}$ An attorney nuust know what his chent did in order to advise him, but legal advice does not require confidentiality in plotting future crinies. Thus, the latter communication is not necessary for the professional relationship and is not privileged. Conversely, in the personal privileges, such as husband-wife, all communications are privileged. ${ }^{98}$ Free communication and preservation of the relationship are the goals of the personal privilege, rather than the effective rendering of a service.

Unfortunately, a TDD relay user-operator privilege under section 225 does not fit neatly into either group of privileges but rather shares characteristics of both. A relay user-operator privilege is similar to a "professional" privilege in that the communication is essential to providing the service. However, unlike other "professional" privileges, no professional advice or counseling flows froin the relay operator to the relay user. The relay operator-user privilege has the characteristics of a "personal" privilege in that it "throw[s] a veil of secrecy around specific zones of privacy in order to protect individual autonoiny and hunian dignity."99 However, the TDD relay operator does not have a personal relationship with the relay users. The only personal relationship is between the relay users, and that relationship is not privileged. Either of the relay users may be called upon to testify to the substance of their conversation, ${ }^{100}$ assuming no preexisting privilege exists, but with a relay useroperator privilege, the operator could not.

\section{Policies Underlying Privileges}

Two common rationales justify the existence of privileges. The first, known as the utilitarian rationale, focuses on justifying confidential communications "within the context of various professional relationships, e.g., attorney and client, physician and patient, clergyman and peni-

97. Id. at 525 .

98. Id. at 525-26. Of course, this is an oversimplification. Not all states afford complete confidentiality to either relationship. For example, in Texas when child abuse or neglect is at issue only the attorney-client privilege applies. See supra note 92 and accompanying text. However, some states still accord greater protection with fewer content restrictions to "personal" privileges than to "professional" privileges. Thus, for example, Utah's husband-wife privilege covers "any communication made by one [spouse] to the other during the inarriage." UTAH CODE ANN. § 7824-8(1)(a) (1990 Supp.) (emphasis added). In contrast to the level of protection afforded personal communications, the physician-patient privilege extends only to "information acquired in attending the patient which was necessary to enable [the physician] to prescribe or act for the patient." Id. § 78-24-8(4).

99. E. GREen \& C. Nesson, supra note 96, at 526.

100. The hearsay rule, however, might limit the use of out of court statements offered for the truth of the matter asserted. FED. R. Evid. 802. 
tent."101 This approach, espoused chiefly by Dean Wigmore, holds that these privileges are justified in order to encourage full communications within these relationships. ${ }^{102}$

Wigmore beheved that there were four essential conditions for the establishment of such a privilege:

(1) The communications nust originate in a confidence that they will not be disclosed.

(2) This elenient of confidentiality nuust be essential to the full and satisfactory maintenance of the relation between the parties.

(3) The relation nust be one which in the opinion of the conımunity ought to be sedulously fostered.

(4) The injury that would inure to the relation by the disclosure of the comnunications must be greater than the benefit thereby gained for the correct disposal of hitigation. ${ }^{103}$

Although these conditions might be interpreted quite broadly, Wigmore did not do so. Rather, he construed thein strictly, justifying traditional privileges such as that protectimg attorney-chent communications but refusing to recognize new ones. ${ }^{104}$

Courts also have strictly mterpreted the conditions mandating privileges. In particular, most courts ouly consider systemic harms when evaluating Wigmore's mjury requirement. ${ }^{105}$ Ignoring the harm to the individual in the specific case, ${ }^{106}$ courts instead attempt to balance the beneflt of protecting the class of communications against the cost to the goal of truth-seeking. ${ }^{107}$

Numerous commentators have criticized the assumptions underlying the utilitarian justification for privileges. ${ }^{108}$ The chief attack questions whether existing privileges actually encourage communications at all. ${ }^{109}$ Critics argue that people typically do not know of or understand

101. MCCORMICK ON EVIDENCE, supra note $72, \S 72$, at 171.

102. Id.

103. $8 \mathrm{~J}$. WIGMORE, EVIDENCE IN TRIALS AT COMMON LAW $\$ 2285$, at 527 (McNaughton rev. ed. 1961) (emphasis omitted).

104. Id. at 527-28 (arguing that a privilege should not protect telegraph communications); see also Note, supra note 79 , at $1472-73$ (discussing Wigmore's interpretation of privileges).

105. Note, supra note 79, at 1473; see, e.g., Upjohn Co. v. United States, 449 U.S. 383, 389 (1981) (need for attorney-client privilege analyzed in terms of public's need for confidential legal advice); United States v. Nixon, 418 U.S. 683, 712 (1974) (analyzing presidential privilege in terms of the effect on future presidential advisers).

106. Note, supra note 79 , at 1473.

107. See, e.g., Nixon, 418 U.S. at 712-13 ("A President's acknowledged need for confidentiality in the communications of his office is general in nature, whereas the constitutional need for production of relevant evidence in a criminal proceeding is specific and central to the fair adjudication of a particular criminal case in the administration of justice.").

108. See, e.g., MCCORMICK ON EvIDENCE, supra note 72, \& 77, at 186-87 (observing that the traditional justification leads to the "assertion of highly questionable sociological premises").

109. See, e.g. Note, The Attorney-Client Privilege and the Corporation in Shareholder Litigation, 50 S. CAL. L. REv. 303, 306 (1977) (authored by H. Richard Dallas) ("[N]o empirical data is 
the privileges. ${ }^{110}$ Defenders of privileges counter that although the benefits of privileges are difficult to quantify, they are significant and outweigh the costs to the truth-seeking function. ${ }^{111}$ Defenders also point out that the costs involved are difficult to estimate and tend to be overstated. ${ }^{112}$

The second justification for privileges is that they protect certain privacy interests. ${ }^{13}$ While the utilitarian justification looks only to prevent widespread systemic harms to a class, the privacy rationale is concerned with harm to the individual communicant. ${ }^{114}$ Thus, communication within certain relationships should not be pried into, not because the privileges promote commumication but because the relationship is an essentially private one.

\section{B. Exclusionary Rules}

Rather than as a privilege, section 225 might be interpreted as an exclusionary rule. Privileges and exclusionary rules have similar effects upon a criminal proceeding: both exclude relevant evidence froin a court in order to further their goals. For privileges, the goal is preservation of a relationship. ${ }^{115}$ For exclusionary rules, the goal is generally deterrence of inappropriate behavior by law-enforceinent officials. ${ }^{116}$ Exclusionary rules have been used, as have privileges, to protect private communications. For example, federal law uses an exclusionary rule to protect telephone privacy, ${ }^{117}$ a goal characteristic of a privilege. Thus, the privacy of TDD relay users could be protected by either a privilege or an exclusionary rule.

Exclusionary rules developed as a tool to enforce the fourth aniendment and have since been applied to enforce various statutory prohibitions. In statutes, exclusionary rules nay be implied by the courts or

available which will accurately demonstrate whether the privilege actually encourages communications between attorneys and their clients."); Note, Functional Overlap Between the Lawyer and Other Professionals: Its Implications for the Privileged Communications Doctrine, 71 YALE L.J. 1226, 1236 (1962) [hereinafter Functional Overlap] (survey indicates that attorney-client privilege may not encourage communications because most clients are unaware of the privilege).

110. See, e.g., Functional Overlap, supra note 109, at 1236.

111. See generally Note, supra note 79 , at $1474-80$ (discussing the value of privileges to relationships between professionals and their clients).

112. See id. at 1477-79 (considering the cost of recognizing privileges).

113. See MCCORMICK ON EVIDENCE, supra note $72, \S 72$, at 172 ; Note, supra note 79 , at $1480-$ 83.

114. See Note, supra note 79, at $1480-81$. For examples of the use of the privacy ratiouale see Black, The Marital and Physician Privileges-A Reprint of a Letter to a Congressman, 1975 DUKE L.J. 45, 48 (defending marital confidentiality privilege on privacy grounds); Saltzburg, supra note 76, at 618-21 (defending doctor-patient and psychotherapist-patient privileges on privacy grounds).

115. See supra text accompanying notes 101-114 (discussing the policies underlying privileges).

116. See infra text accompanying notes 191-205 (discussing the three rationales generally offered in support of exclusionary rules).

117. See infra text accompanying notes 149-63. 
explicitly enacted by the legislature. ${ }^{118}$ This Part will discuss the use of exclusionary rules to protect conversational privacy in three contextsthe fourth amendment, and imphicit and explicit statutory schemes-and then consider various policy rationales that support the use of exclusionary rules.

\section{The Fourth Amendment Exclusionary Rule}

The Supreme Court first apphied a constitutional exclusionary rule in Weeks v. United States, ${ }^{119}$ reversing a lower federal court conviction because it was based on evidence seized in violation of the fourth amendment. ${ }^{120}$ Although the fourth amendment does not exphicitly address the admissibility of evidence, ${ }^{121}$ the Court regarded an exclusionary rule as the only means to deter improper police actions and to remedy the wrong done to the defendant. ${ }^{122}$ Without such a rule, the Court stated, "the protection of the Fourth Amendment declaring his right to be secure agaimst such searches and seizures is of no value, and, so far as those thus placed are concerned, might as well be stricken from the Constitution."123

Conversations also come under the fourth amendment's protection. In Katz v. United States ${ }^{124}$ the Court defined the fourth amendment's protection of conversational privacy. Federal agents had eavesdropped-through a microphone on the outside of a public telephone booth-on defendant's illegal communication of wagering information. ${ }^{125}$ The Court held that the fourth amendment protected Katz's right to shelter his conversation from the "uninvited ear."126 Justice Harlan's concurring opimon established a twofold test for fourth amendment protection. ${ }^{127}$ First, the person must have exhibited an actual, subjective expectation of privacy and, second, the expectation must be one that society is prepared to recognize as "reasonable."128

118. See infra Parts II.B.2, 3 (discussing Nardone v. United States and title III).

119. 232 U.S. 383 (1914), overruled by Elkins v. United States, 364 U.S. 206, 223 (1960) (holding that evidence seized by state officers, which would be inadmissible if seized by federal officers under similar circumstances, would also be inadmissible).

120. Id. at 393-98.

121. The right of the people to be secure in their persons, houses, papers, and effects, against unreasonable searches and seizures, shall not be violated, and no Warrants shall issue, but upon probable cause, supported by Oath or affirmation, and particularly describing the place to be searched, and the persons or things to be seized.

U.S. CONST. amend. IV.

122. Weeks, 232 U.S. at 393-98.

123. Id. at 393.

124. 389 U.S. 347 (1967).

125. Id. at 348 .

126. Id. at $352-53$.

127. Id. at 361 (Harlan, J., concurring).

128. Id. 
The decision in Katz is relevant to an analysis of section 225 in two ways. First, Congress drafted the federal law that regulates wiretaps and interception and disclosure of telecommunications to conform with the Court's decision in Katz. ${ }^{129}$ This law, title III of the Omnibus Crime Control and Safe Streets Act of $1968,{ }^{130}$ is important in understanding section 225 because it would presumably regulate relay operators had the confidentiality provision in section 225 been omitted.

Moreover, Katz rejected a situation much like the "bemign momitoring" of private conversations that would exist for TDD relay users if relay operators were allowed to report crimes. In Katz the agents had accidentally intercepted an innocent call from the telephone booth before they listened to the defendant's call. ${ }^{131}$ The agents properly refrained from listening to the innocent conversation, the Court said. However, limitimg their interceptions to illegal calls did not allow the agents to use the evidence obtamed. ${ }^{132}$ Rather, without a warrant issued upon probable cause, all fruits of the wiretap were illegal. The defendant was "surely entitled to assume that the words he utters into the mouthpiece will not be broadcast to the world. To read the Constitution more narrowly is to ignore the vital role that the public telephone has come to play im private comnunication."133

A TDD relay system without protection for all conversations would be similar to the government's position rejected im Katz for voice telephone users. The argument for allowing TDD relay operators to report crinies, and for allowing agents to benignly nionitor calls, is that ouly the criminal need fear-innocent callers may say whatever they like. In Katz the Court rejected allowing a third person to histen to a telephone call without probable cause. The parallel solution in the TDD relay situation, in which a third person must listen, is to legally silence that person.

\section{Implicit Statutory Exclusionary Rules}

A court may imply an exclusionary rule in the absence of a specific statutory provision. In Nardone v. United States (Nardone $I^{134}$ the Suprenie Court applied an exclusionary rule to protect telecommunications privacy, excluding the fruits of a wiretap that violated section 605 of the Communications Act of $1934 . .^{135}$ In Nardone I federal agents

129. S. ReP. No. 1097, 90th Cong., 2d Sess. 66, reprinted in 1968 U.S. CODE CONG. \& ADMiN. NEwS 2112, 2153.

130. Omnibus Crime Control and Safe Streets Act of 1968, Pub. L. No. 90-351, tit. III, 82 Stat. $197,211-25$ (codified as amended at 18 U.S.C. $\$ \S 2510-2520$ (1988)).

131. Katz, 389 U.S. at 354 n.15.

132. Id. at 356-57 (noting that the officers' use of restraint in the course of their surveillance did not make up for the lack of a warrant).

133. Id. at 352.

134. 302 U.S. 379 (1937).

135. Id. at 382 (reading $\S 605$ as providing that " 'no person' shall divulge or publish the 
wiretapped the telephone of a bootlegger and testified at trial to the substance of overheard communications. ${ }^{136}$ The Court held that this violated section 605 , which provided that " 'no person not being authorized by the sender shall intercept any communication and divulge or publish the existence, contents, substance, purport, effect or meaning of such intercepted communication to any person." "137

Justice Roberts, writing for the majority, relied on the plain words of the statute: "Taken at face value the phrase 'no person' comprehends federal agents, and the ban on communication to 'any person' bars testimony to the content of an intercepted niessage." 138 This interpretation was supported, the Court argued, by another part of section 605 that allowed disclosure under a subpoena, while the portion at issue contained no such clause. ${ }^{139}$ The congressional policy underlying the exclusion of the evidence, the Court stated, was to discourage officers from resorting to "nrethods deemed inconsistent with ethical standards and destructive of personal liberty." 140

Two years after Nardone $I$ the Suprenie Court revisited the same issue in Nardone $I I^{141}$ and expanded the exclusionary rule invoked in the earhier decision. The defendant had been convicted in a second trial without testimony from the wiretaps. However, the trial court refused to allow the accused to exanine the prosecution as to the uses to which it had put the forbidden wiretap evidence, "leaving the prosecution free to make every other use of the proscribed evidence."142

Nardone II excluded the derivative evidence from the illegal wiretap. Justice Frankfurter, for the majority, wrote:

Any claim for the exclusion of evidence logically relevant in criminal prosecution is heavily handicapped. It must be justified by an overriding public policy expressed in the Constitution or the law of the land. In a problem such as that before us now, two opposing concerns must be harmomized: on the one hand, the stern enforcement of the crinninal law;

message or its substance to 'any person" " (referring to 47 U.S.C. $\S 605$ (1988))) (emphasis in original).

136. Id. at 380.

137. Id. at 381 (quoting 47 U.S.C. $\S 605(\mathrm{a})$ (1988)).

138. $I d$.

139. The Court said in Nardone $I$ that $\S 605$

provides that no person ... [involved in] the sending or receiving of any interstate communication by wire shall divulge or publish it or its substance to anyone other than the addressee or his authorized representative or to authorized fellow employes [sic], save in response to a subpoena ... or on demand of other lawful authority; and "no person not being authorized by the sender shall intercept any communication and divulge or publish the existence, contents, substance, purport, effect or meaning of such intercepted communication to any person[.]"

Id. at 380-81.

140. Id. at 383 .

141. Nardone v. United States, 308 U.S. 338 (1939).

142. Id. at 339. 
on the other, protection of that realm of privacy left free by Constitution and laws but capable of infringement either through zeal or design. In accommodating both these concerns, meaning must be given to what Congress has written, even if not in explicit language, so as to effectuate the policy which Congress has formulated. ${ }^{143}$

According to the Court, allowing use of the derivative evidence would thwart the congressional policy of protecting individual privacy embodied in section $605 .{ }^{144}$ The Court held that the defendant should be allowed to prove that the prosecution's evidence was an excludable "fruit of the poisonous tree."145 The government, then, was left free to prove that the evidence had an independent source; but only if there was such an independent source might the taint of the illegal wiretap become so attenuated as to dissipate. ${ }^{146}$

The Nardone decisions and their interpretation of section 605 provide a basis for inferring an exclusionary rule in interpreting section 225 . Both statutes were drafted in broad language to protect communications confidentiality. ${ }^{147}$ Moreover, despite initial criticism of the Nardone decisions, ${ }^{148}$ the exclusionary rule invoked there lasted until it was codified by the enactment of title III.

\section{Title III: The Federal Wiretap Statute's Explicit Exclusionary Rule}

Title III replaced section 605 , the statutory basis for the Nardone decisions, as the principal statute governing interception and disclosure of conimunications and changed some elements of the section 605 frainework. ${ }^{149}$ In its original forn, section 605 covered all interceptors of comniunications. ${ }^{150}$ As ainended by title III, section 605 prohibits only wirecommunications providers from disclosing communications to any person, with exceptions as authorized. ${ }^{151}$ Furtherniore, the Senate report acconipanying title III specified that any "person" did not include lawenforcement officials acting in the nornal course of their duties, thereby

143. Id. at 340 .

144. Id.

145. Id. at 341 .

146. Id.

147. See supra note 139 and text accompanying note 11 .

148. Legislation that would have overruled the Nardone decisions passed both houses of Congress in 1938, but the session ended before a compromise version was enacted. OFFICE of Technology Assessment, Federal Government lNFormation Technology: Electronic SURVEILlaNCE AND CIVIL Liberties $32 \& \mathrm{n} .13$ (1985).

149. Section 802 of the Act added chapter 119 to title 18 of the U.S. Code (codified at 18 U.S.C. $\S \S 2510-2520$ ). Section 803 of the Act amended 47 U.S.C. $\S 605$ so as to give precedence to the provisions of chapter 119. 47 U.S.C. $\$ 605$ (a) (1988).

150. See Communications Act of 1934, Pub. L. No. 73-416, § 605, 48 Stat. 1064, 1103-04.

151. See 47 U.S.C. $\$ 605(a)$ (1988) (covers any person "receiving, assisting in receiving, transmitting, or assisting in transmitting, any ... communication"). 
removing section 605 as a check on law enforcement. ${ }^{152}$ The Senate report on title III, however, expressed an intent to keep the exclusionary rules as stated by the Nardone decisions. ${ }^{153}$

The major purpose of title III was to combat organized crime, ${ }^{154}$ but another purpose was to protect communications privacy. ${ }^{155}$ Thus, title III reflects the tension between the "stern enforcement of the criminal law ... [and the] protection of that realm of privacy left free by Constitution and laws."156 Title III generally prohibits the unauthorized interception, ${ }^{157}$ disclosure, or use as evidence of wire, oral, and electronic communications. ${ }^{158}$ A "reasonable expectation of privacy" is required for the protection of oral commumications; ${ }^{159}$ wire and electronic communications are protected without that expectation. ${ }^{160}$ Title III also provides detailed procedures for judicial authorization of law-enforcement wiretapping or electronic surveillance. ${ }^{161}$ Civil and criminal penalties attach if communications are intercepted or disclosed in violation of the statute. ${ }^{162,}$ Evidence that could not be disclosed may not be received as evidence in any court proceeding. ${ }^{163}$

152. S. REP. No. 1097, supra note 129, at 108, reprinted in 1968 U.S. CODE CoNG. \& ADM1N. NEwS at 2196.

153. Id. at 96, reprinted in 1968 U.S. CoDE CONG. \& ADMIN. NEWS at 2185.

154. Id. at 70, reprinted in 1968 U.S. CODE CONG. \& ADMIN. NEWS at 2157.

155. Id. at 66, reprinted in 1968 U.S. CODE CONG. \& ADMIN. NEWS at 2153.

156. Nardone v. United States (Nardone II), 308 U.S. 338, 340 (1939).

157. Section $2510(4)$ provides: " 'intercept' means the aural or other acquisition of the contents of any wire, electromic, or oral communication through the use of any electronic, mechanical, or other device." 18 U.S.C. § 2510(4) (1988).

158. See id. § $2511(1)$. TDD relay conversations would be "wire communications" under the definition of that term in 18 U.S.C. $\S 2510$ (1) (1988).

159. Id. $\S 2510(2)$ (providing that an “'oral communication' means any oral communication uttered by a person exhibiting an expectation that such communication is not subject to interception under circumstances justifying such expectation"); see Katz v. United States, 389 U.S. 347, 361 (1967) (Harlan, J., concurring) (stating that, under fourth amendment analysis, protection of communications requires a reasonable expectation of privacy).

160. 18 U.S.C. § $2510(1),(2),(12)$ (1988).

161. Id. $\S \S 2518-2519$ (these sections provide for an extensive application process that requires the police to submit complete statements of the facts and purposes of the wiretap and that includes procedural guidelines and reporting requirements for judges).

162. Section 2511(1) provides:

Except as otherwise specifically provided in this chapter any person who-(a) intentionally intercepts . . . any wire, oral, or electronic communication; [or] . . (c) intentionally discloses, or endeavors to disclose, to any other person the contents of any wire, oral, or electronic communication ... obtained ... in violation of this subsection ... shall be punished as provided in subsection (4) or shall be subject to suit as provided in subsection (5).

Id. $\S 2511(1)$.

Section 2511(4) provides for criminal penalties and $\S 2511(5)$ provides for civil penalties. $I d$. § 2511(4), (5).

163. Section 2515 provides:

Whenever any wire or oral communication has been intercepted, no part of the contents of such communication and no evidence derived therefrom may be received in evidence in any trial, hearing, or other proceeding in or before any court, grand jury, department, officer, 
Title III provides exceptions to its exclusionary rule and protects providers of wire and electronics communications from liability in several ways. First, section 2511 allows communications workers to intercept, use, and disclose communications to protect their companies' "rights or property." 164 For instance, in United States v. Clegg ${ }^{165}$ the telephone company monitored and recorded the calls of an individual suspected of using a "blue box" to avoid long distance cliarges. ${ }^{166}$ The court admitted the recordings in the defendant's trial for wire fraud, holding that such interception and disclosure did not violate title III because section 2511(2)(a) allows a telephone company to protect the integrity of the telephone system. ${ }^{167}$ However, company surveillance may not be undertaken as a pretext at police instigation ${ }^{168}$ or extended beyond what is necessary to satisfy reasonable business needs. ${ }^{169}$

In addition, section $2510(5)$ defines "electronic, mechanical, or other device" so as to exclude "any telephone or telegraph instrument, equipment or facility, or any component thereof, . . . being used by a provider of wire or electronic communication service in the ordinary course of its busmess." 170 Consequently, an "interception" cannot occur if the intercepting device is of the type defined in section 2510(5). Also, section 2511 allows a communication worker to intercept, use, and disclose a communication intercepted in the "normal course of his employment." "171 Because a communication intercepted in this inanner has not been intercepted unlawfully, communications workers may disclose the content of such a communication, although disclosure would not ordinarily be "in the normal course" of employment. United States v. Ross ${ }^{172}$ typifies this approach. In Ross a telephone lineman performing service checks overheard and reported conversations involving explosives. ${ }^{173}$ The court held that his testimony was justified as consistent with the

agency, regulatory body, legislative committee, or other authority of the United States, a State, or a political subdivision thereof if the disclosure of that information would be in violation of this chapter.

Id. $\S 2515$.

164. Id. § $2511(2)(\mathrm{a})(\mathrm{i})$.

165. 509 F.2d 605 (5th Cir. 1975).

166. Blue boxes reroute long distance toll calls through the toll-free 800 network. See United States v. Douglas, 510 F.2d 266, 267 (9th Cir. 1975) (describing the function and use of "blue boxes").

167. Clegg, 509 F.2d at $612-13$ (citing 18 U.S.C. $\$ 2511$ (2)(a) (1988)).

168. People v. Rogers, 46 Misc. 2d 860, 862-63, 261 N.Y.S.2d 152, 154-55 (Seneca Co. Ct. 1965) (police instructed switchboard operator to eavesdrop on defendant's calls in order to obtain information necessary to support lega: wiretap).

169. Commonwealth v. Helms, 234 Pa. Super. 537, 548-49, 343 A.2d 362, 367 (1975); J. CARR, The LAW OF Electronic SuRVeillanCE § 3.3(e)(2), at 3-54 to 3-55 (1986, updated April 1989).

170. 18 U.S.C. $\S 2510(5)$ (a) (1988).

171. Id. $\S 2511(2)(\mathrm{a})(\mathrm{i})$.

172. 713 F.2d 389 (8th Cir. 1983).

173. Id. at 390 . 
"deeply rooted social obligation" to report felonies. ${ }^{174}$

The "normal course of employment" exception has been criticized as a "classic example of the exception swallowing the rule."175 One commentator argued that the exemption for communications workers appropriately allows them to perform their duties without incurring liability for interceptions. However, their duties do not include disclosing conversations to law-enforcement officers, and such disclosure should be prohibited as outside the normal course of employment. ${ }^{176}$

Courts have been overly generous, however, in applying the exceptions for commumications workers. United States v. Axselle ${ }^{177}$ typifies the reluctance of the courts to apply the title III exclusionary rule. ${ }^{178}$ In Axselle, a motel switchboard operator connected a telephone call froin outside the motel to Axselle's codefendant, Claiborne. ${ }^{179}$ She overheard the caller ask if anyone had been near the trunk of Claiborne's car. ${ }^{180}$ The caller then began talking about the "stuff" they had and that there was a lot of money involved. ${ }^{181}$ The operator became interested, and listened to the conversation for three to five minutes. ${ }^{182}$ Claiborne asked the caller for money to replace the tires on his car because " the county mounties hung around the gas station and he didn't want attention drawn to his car with the bad tires he had." "183 After the call, the motel switchboard operator informed the motel manager who then relayed the information to the police. The police transferred the information to the U. S. Attorney's Office, which obtamed a search warrant for Claiborne's car and found approximately 100 pounds of marijuana in the trunk. ${ }^{184}$

The Axselle court denied the motion to suppress the evidence from

174. Id. at 392 (quoting Roberts v. United States, 445 U.S. 552, 558 (1980)). In Roberts the Supreme Court allowed the trial court during sentencing to consider a defendant's refusal to identify his cohorts. Roberts, 445 U.S. at 556. As Roberts did not involve a conflicting exclusionary rule to protect privacy, the reliance on this case in Ross is misguided.

175. Note, The Electronic Communications Privacy Act of 1986: The Challenge of Applying Ambiguous Statutory Language to Intricate Telecommunieation Technologies, 13 RUTGERS COMPUTER \& TECH. L.J. 451, 492 (1987) (authored by Russel S. Burnside).

176. Id. at 492-95. But see Note, Voices that Go Bump in the Night: Conflicting Rights Under the Wiretap Statutes, 11 SETON HALL LEG1S. J. 171, 197-98 (1987) (authored by Steven M. Richman) (suggesting that preventing disclosure by inadvertent interceptors would violate flrst amendment right to free speech).

177. 604 F.2d 1330 (10th Cir. 1979).

178. See also State v. McCartin, 135 N.J. Super. 81, 88, 342 A.2d 591, 595 (Law Div. 1975) (conversations overheard on malfunctioning telephone admissible under a state statute identical to 18 U.S.C. § 2510); J. CARR, supra note 169, §3.2(c)(2)(G), at 3-37 (acknowledging that conversations inadvertently overheard on a party line, because of an equipment malfunction, by a long distance operator, or by a motel switchboard operator have been held not violative of title II1).

179. Axselle, 604 F.2d at 1332.

180. Id.

181. Id.

182. Id. at 1334-35.

183. Id. at 1332.

184. Id. 
the telephone call and the resulting search. ${ }^{185}$ Relying upon the trial court's finding that the inotel operator's interception of the call was inadvertent, the court stated that the interception was not illegal as section 2511 only criminalizes willful interceptions. ${ }^{186}$ The court's decision is supported by other cases in which telephone linemen ${ }^{187}$ and long distance operators ${ }^{188}$ have been allowed to disclose overheard conversations even when it appeared from the anount overheard that they continued to listen past the point necessary to inonitor service.

Thus, courts seen to believe that Congress approved of the disclosure of criminal conversations inadvertently overheard by communications workers. In 1986, $\mathrm{n}_{1}$ fact, Congress amended title III to expressly permit electronic communication service workers to divulge communications "which were niadvertently obtained by the service provider and which appear to pertain to the conımission of a crime, if such divulgence is made to a law enforcentent agency." 189 This ainendnient created an exception for electronic communications, signalling congressional approval of the application of this exception in the courts.

Why would Congress allow telephone conpany workers to histen to a conversation and report it to the police, yet exclude such evidence if the police had histened to the conversation? Considering the dual objectives of title III, crime prevention and privacy, provides a possible answer. Congress seems to equate privacy with the mimimun anount of telephone inonitoring. Because coininunications workers nuust inonitor some ainount of calls to provide their service, excluding from evidence such calls will presumably not reduce monitoring. In addition, some number of telephone calls will be nonitored inadvertently, either by the operator or another caller on a party line. Excluding these calls from evidence will not affect the frequency of norntoring. Conversely, allowing police officers to use intercepted calls as evidence would give thein an incentive to nonitor more calls, threatening privacy. Thus, section 2515 excludes such calls as evidence. ${ }^{190}$

185. Id. at 1335.

186. Id. at 1333-35. The court did not separate out the analysis for exclusion, however. Since the interception was not "illegal" (the operator could not be criminally punished under $\S 2511$ ), the court admitted the evidence. See id. at 1335.

187. United States v. Ross, 713 F.2d 389 (8th Cir. 1983). But cf. Tavernetti v. Superior Court, 22 Cal. 3d 187, 583 P.2d 737, 148 Cal. Rptr. 883 (1978) (holding that under a California wiretap statute, a telephone lineman may not listen any longer than necessary to hear intelligible words).

188. People v. Sierra, 74 Misc. 2d 332, 335-36, 343 N.Y.S.2d 196, 200 (Sup. Ct. 1973). But see State v. Dwyer, 120 Ariz. 291, 295, 585 P.2d 900, 904 (Ariz. Ct. App. 1978) (evidence suppressed because operator listened for ten to fifteen minutes).

189. Act of Oct. 21, 1986, Pub. L. 99-508, $\S 102,100$ Stat. 1853 (codified at 18 U.S.C. $\S 2511(3)(\mathrm{b})(\mathrm{iv})(1988))$.

190. See J. CARR, supra note $169, \S 3.2(c)(2)(G)$, at $3-37$ (discussing how courts use inadvertency as a criterion in applying the exclusionary rule). 


\section{Policies Underlying Exclusionary Rules}

Defenders usually look to the three reasons advanced in support of exclusionary rules in Mapp v. Onio. ${ }^{191}$ Although these arguments developed in the context of a fourth amendment exclusionary rule, ${ }^{192}$ they can provide guidance in considering other possible exclusionary rules. ${ }^{193}$

The major, and perhaps only surviving, reason for a fourth amendment exclusionary rule is to deter illegal police conduct. ${ }^{194}$ Prohibiting the use of improperly seized evidence in a crimmal proceeding removes the incentive for police to ignore the dictates of the fourth amendinent. ${ }^{195}$ This rationale provides a convincing justification for fourth amendment suppression, but offers little basis for excluding evidence offered by commumications workers in the title III framework or by TDD relay operators under section 225 .

The second rationale, "the inperative of judicial integrity," mandates that courts refram from participating in the wrong perpetrated on the defendant. ${ }^{196}$ This justification has been narrowly interpreted by the Supreme Court since Mapp. In Janis $v$. United States ${ }^{197}$ the Court commented that the judicial integrity rule means only that a court "must not commit or encourage violations of the Constitution." 198 Moreover, regardless of whether or not the court feels its internal integrity has been preserved, the public arguably often views exclusionary rules as mere "technicalities" that free criminals; thus, the public perception of judicial integrity might be more harmed than helped by these rules. ${ }^{199}$ However, despite this narrow interpretation of the fourth amendment, a court might still consider the effect on judicial integrity when applying an exclusionary rule in other contexts. ${ }^{200}$ Thus, a court could justify excludmg a disclosed TDD relay conversation simply because the violation of section 225 brought it into court. By using the conversation as evidence, a court would harm judicial integrity by participating in and encouraging violations of the statute.

191. 367 U.S. 643 (1961).

192. Mapp held that evidence seized in violation of the fourth amendment is inadmissible in a state court. Id. at 655 .

193. See MCCORMICK ON EVIDENCE, supra note $72, \S 168$, at $460-66$.

194. See Stuntz, The American Exclusionary Rule and Defendants' Changing Rights, 1989 CRIM. L. REv. 117, 118-19, 122 (1989) (arguing that judicial integrity and defendants' personal rights have been abandoned as exclusionary-rule rationales).

195. See Mapp, 367 U.S. at 656; MCCORMICK ON EvIDENCE, supra notc 72, § 168, at 461.

196. Mapp, 367 U.S. at 659 (quoting Elkins v. United States, 364 U.S. 206, 222 (1960)).

197. 428 U.S. 433 (1976).

198. Id. at 458 n.35 (recognizing that this interpretation merged the judicial integrity rationale with the deterrence rationale); see also MCCORMICK ON Ev1DENCE, supra note 72, $\$ 168$, at 462 (arguing that courts must set a good example by refusing to recognize illegally obtained evidence).

199. See MCCORMICK ON EvidENCE, supra note $72, \S 168$, at 462,464 (suggesting that the public reputation of the judiciary is diminished by its enforcement of exclusionary rules).

200. Id. at 462 . 
The third rationale justifies exclusionary rules as a personal remedy for the invasion of the defendant's privacy: Only suppression of the improperly obtained evidence can insure that a defendant is subject to the saine risk of conviction as he would have had if no violation had occurred. $^{201}$ The Court has rejected this rationale as applied in fourth amendinent cases. ${ }^{202}$ The rejection of the personal reinedy rationale flows from the basic premise that a criminal does not have a right to commit crimes and then escape conviction. ${ }^{203}$ Thus, even if his privacy rights are violated, he has no right to have evidence excluded at trial ${ }^{204}$ the violation of his privacy right can be otherwise redressed. The negative response to this rationale in the fourth amendment context does not preclude a court from applying exclusion as a personal reinedy in another context, however. ${ }^{205}$ Section 225 might be interpreted to give a TDD relay user a personal right to as much protection for conversational privacy as a voice telephone user receives. In such a case, an exclusionary rule would be proper.

III

\section{ANALYSIS}

The starting point for analysis of section 225 is deciding whether criminal conversations should be afforded any confidentiahty at all. This Part considers that question and answers it affirmatively. The next issue will be how to protect those conversations. The proposed solution will have three parts: (1) FCC civil and criminal penalties for disclosing conversations; (2) an evidentiary privilege that allows operators to refuse to answer subpoenas about past conversations; and (3) an exclusionary rule that forbids courts froin hearing disclosed conversations and evidence derived froin them.

\section{A. Are Criminal Conversations Protected at All?}

Simply, yes. The sweep of the statutory language and policy considerations weigh in favor of protecting criminal conversations. First, section 225 provides for confidentiality without any exceptions or qualifying provisions. This approach differs from that of title III. Congress approached the relay operator-user as a new relationship, one requiring special guarantees of confidentiality. Second, an analysis of confidential-

201. Id. at $462-63 \&$ n.16.

202. See Stone v. Powell, 428 U.S. 465, 486 (1976) (quoting Linkletter v. Walker, 381 U.S. 618, 637 (1965)) ("Post-Mapp decisions have established that the [exclusionary] rule is not a personal constitutional right. It is not calculated to redress the injury to the privacy of the victim of the search or seizure . . . ."); see also MCCORMICK ON EVIDENCE, supra note 72, § 168, at 463.

203. See MCCORMICK ON EVIDENCE, supra note $72, \S 168$, at 463.

204. Id.

205. Id. 
ity in light of the policies surrounding exclusionary rules and privileges demonstrates that protecting criminal relay conversations is a reasonable goal that should be vigorously defended.

\section{Statutory Language Revisited - "Functionally Equivalent" Service}

The ADA mandates "functionally equivalent" telecommunications access for hearing- and speech-impaired individuals. ${ }^{206}$ This provision supports confidentiality for criminal relay conversations. An important aspect of the telecommunications network is the ability to exclude the world from knowledge of conversations. This ability to exclude unwanted histeners has received legislative and judicial protection even when criminal conversations are at issue. ${ }^{207}$ Thus, a hearing individual may make a criminal telephone call without risk that the conversation will be disclosed in court by a third party, provided that a legal wiretap has not been issued and a commurncations worker does not inadvertently overhear the conversation. If "functionally equivalent" service is to be provided to the TDD relay user, the relay operator must be legally gagged.

This interpretation of functional equivalency is supported by considering the $\mathrm{ADA}$ as a remedial civil rights measure that should be interpreted broadly. ${ }^{208}$ Any judicially crafted exception to the nondisclosure requirement should be viewed with extreme suspicion because it would discriminate against deaf individuals. The relay users will be under much greater risk of police intrusion into their affairs if disclosure of criminal conversations is allowed. Although forbidding such discrimination inay cost by encouraging crime, forbidding discrimination against individuals with disabilities, not deterring crime, was the purpose of the ADA. ${ }^{209}$

On the other hand, "functional equivalency" might not include an equivalent ability to commit crime. Congress clearly intended to give the hearing- and speech-impaired communities access to the telephone systein. This access was calculated to improve the economic and social opportunities of TDD users. ${ }^{210}$ However, Congress might have drawn the hine at an equivalent opportunity to coinnit, plan, and conceal crimes over the telephone. If protecting all conversations from inonitoring was

206. 47 U.S.C.A. § 225(a)(3) (West 1991).

207. An improperly intercepted communication may be excluded from a criminal proceeding even if it reveals criminal conduct, 18 U.S.C. $\$ 2515$ (1988); see, e.g., Katz v. United States, 389 U.S. 347 (1967) (fourth amendment violated by improper interception of telephone conversation).

208. Other remedial civil rights legislation has been "construed generously to further its primary purpose." Gomez v. Toledo, 446 U.S. 635, 639 (1980). Eskridge and Frickey identify this as a canon of statutory construction. W. ESKRIDGE \& P. FRICKEY, CASES AND MATERIALS ON LEGISLATION 656 (1988).

209. Americans with Disabilities Act of 1990, 42 U.S.C.A. $\S 12101$ (b) (West 1991).

210. See SenAte Disabilities RePort, supra note 2 , at 78. 
the goal, granting criminal conversations confidentiality could be considered a necessary evil serving that end. But, because the TDD relay service inust give a third person knowledge of every conversation, protecting criminal conversations cannot protect against third-party knowledge of any given conversation. Congress may protect noncriminal conversations by prohibiting their disclosure, and deny protection to criminal conversations witliout any additional monitoring taking place.

The similarity of the relay operator and the switcliboard operator also supports the proposition that criminal conversations should be disclosed. Since title III allows a switchboard operator who inadvertently overhears a criminal conversation to disclose it to law-enforcement officials, ${ }^{211}$ "functional equivalency" miglit allow a relay operator to make the same disclosure. Furthermore, the ADA's silence on criminal disclosure could be interpreted as an adoption of the title III approacli.

But the title III approach slould not be incorporated into the ADA for several reasons. First, the ADA confidentiality provision does not inake any reference to title III or to section 605 . In contrast, when Congress wanted to allow for disclosure of criminal conversations by communication workers in section 605 it amended that section to forbid disclosure to any person except as "autliorized by Title III."212 The absence of sucli positive measures to distinguish between the treatment of criminal and noncriminal conversations in the ADA miglit indicate a decision not to follow the title III approach.

The urique character of the relay operator-user relationship should caution against blindly adopting the rules governing communications workers in section 605 and title III. A relay operator is essential to TDD relay communications. In contrast, intervention of a switcliboard operator is unusual and brief. In order to protect her privacy, a voice telephone user inay curtail lier conversation in those rare instances in whicl an operator might still be listening, such as immediately after a call is connected. A TDD relay user lias no such option. To the extent that slie does not trust the silence of the relay operator, she must forgo use of the relay network. The relay operator's silence is the relay user's only guarantee of privacy; "functionally equivalent" service to the relay user requires that silence be as absolute as if the relay operator liad been a telephone line.

The provision of a special confidentiality rule for relay operators in section 225 also weighs against adopting the title III approacli. Without the confidentiality provision in section 225 , a relay operator would presumably fall witlin the nondisclosure provisions of section 605 as a "per-

211. See supra notes $177-86$ and accompanying text.

212. 47 U.S.C. $\S 605$ (1988). See supra notes $150-51$ and accompanying text (discussing amendments to $\S 605$ ). 
son receiving, assisting in receiving, transmitting, or assisting in transmitting" a wire communication. ${ }^{213}$ Section 605 would prevent a relay operator from disclosing noncriminal conversations but allow the disclosure of criminal conversations in accordance with title $\mathrm{III}^{214}$ Allowing relay operators to disclose criminal conversations would render moot the enactment of section 225's stricter confidentiality provision.

Finally, protection of criminal conversations under the ADA might also be defended because several states that have established their own TDD relay systems do afford such protection, at least im practice. The California Relay Service states in its informational materials that "an essential part of telephone service is privacy."215 Cahifornia Relay Service's pohicy is to not "try to judge whether a call is either obscene or illegal."216 At least one state has gone further, according TDD relay commumications an evidentiary privilege in all civil and criminal proceedings. ${ }^{217}$ While Congress did not exphicitly incorporate these approaches in the ADA, they provide a context for what Congress inight lave intended in the confidentiality provision.

\section{Why Should Criminal Conversations Be Protected?}

The broad language of section 225 should be interpreted to protect all conversations. Althougli a pohicy analysis cannot reveal what Congress actually intended, it can reveal the relevant factors that justify reading the statute to protect all conversations regardless of content. Thus, this policy analysis is directed at ascertaming the best interpretation of section 225. Mucll of the analysis is inconclusive, and rests upon unverifiable empirical assuinptions about the effects of confidentiality and privilege on cominumications. However, the cost-benefit questions that arise in considerimg rules of privilege or exclusion never conclusively support one side. Rather, I will show that protecting criminal relay conversations is a reasonable pohicy. ${ }^{218}$

\section{a. Benefits of Communications Confidentiality}

Alan Westin describes the individual's coinpeting needs of privacy and social interaction in his book Privacy and Freedom. ${ }^{219}$ An individual

213. 47 U.S.C. $\S 605(a)$ (1988).

214. See supra note 212 and accompanying text.

215. California Relay Servicc Brochure, supra note 63; see supra notes $63-66$ and accompanying text.

216. California Relay Service Brochure, supra note 63. However, this protection is not provided by California statute.

217. Conn. Gen. Stat. § 52-146m (1989).

218. I assume that, in passing $\S 225$, Congress did not intend to encourage crime. Instead, the protection of criminal conversations may be justified because it encourages noncriminal relay use, promotes autonomy of relay users, and gives relay users a private communications link.

219. A. WeStiN, PRivacy AND FreEdom 39-42 (1967). 
may suffer from too hittle privacy or from too much. Too much privacy, often forced upon the individual by social or physical conditions beyond his control, can lead to depression or a sense of rootlessness. ${ }^{220}$ The same effects may result from too little privacy. ${ }^{221}$ Society, Westin argues, should allow the individual the opportunity to balance his personal needs for privacy and interaction. ${ }^{222}$

The TDD relay network gives speech- and hearing-impaired individuals an opportunity to counter isolation. The impairments that isolate them from others deny them social and eniployment opportunities. For example, without a relay network, a deaf eniployee could not call his employer in the morning to tell him that his car will not start. "Functionally equivalent" access to telecommunications systems might make the difference between keeping and losing a job for a hearing- or speechimpaired person. Telephone communication also serves as an important channel for personal contact. The TDD relay network allows people with disabilities to form personal bonds as others do, based on mutual interests rather than on the necessity of finding another TDD user. ${ }^{223}$ While correcting the problem of social isolation, the TDD relay network should also respect the need for confidentiality that is the other half of Westin's balance. In recognition of this need, section 225 protects the confidentiality of relay conversations.

The rationales that underhe the roles of privileges and exclusionary rules can be used to analyze the proper extent of confidentiality in TDD communications. ${ }^{224}$ From a nonutilitarian privacy rationale, complete confidentiality should be the rule to avoid interference with private conversations. For voice telephone users, the privacy of telephone lines is fundamental enough to merit constitutional protection. ${ }^{225}$

But confidentiality may also be weighed in a utilitarian cost-benefit analysis. Some degree of confidentiality for relay conversations seems to be a reasonable goal. Two alternatives exist. Relay conversations could be subject to a complete confidentiality requirement that would protect all conversations. Or, limited confidentiality, which would protect only noncriminal conversations, could be appropriate. The deciding issue is

220. Id. at $40-41$.

221. Id. at 41 .

222. Id. at 42 .

223. Testimony about the ADA noted the personal social value of TDD relay services. The services allow TDD users to make theater or dinner reservations or to ask someone out on a date. See SenATE Disabilities Report, supra note 2, at 14.

224. See supra notes 101-14, 191-205, and accompanying text.

225. Katz v. United States, 389 U.S. 347, 352 (1967) ("[A phone user] is surely entitled to assume that the words he utters into the mouthpiece will not be broadcast to the world. To read the Constitution more narrowly is to ignore the vital role that the public telephone has come to play in private communication."). 
whether the benefits of disclosing criminal conversations justify any costs imposed on noncrininal TDD relay users.

The starting point for such a cost-benefit analysis is defining what constitutes a criminal conversation. But this itself is problematic. Although I have generally referred to criminal conversations as though they were distinct and recognizable creatures, they are not. A conversation inight itself be a crime, it imght reveal evidence of a criminal act, it imight reveal a state of mind relevant to a later criminal act, or another of almost endless variations. In hight of these problens, a limited confidentiality rule would likely take one of two forms: Relay operators might be required or allowed to report either all crimes or just serious felonies. ${ }^{226}$

Any limited confidentiality option vests too inuch discretion in the relay operator. ${ }^{227}$ This discretion could allow wide ranges of confidentiality depending on the relay operator and his interpretation of conversations. Furthermore, the relay operator would have the ability to threaten and even blackmail relay users with threats of disclosures if the relay user's identity becaine known.

Moreover, limited confidentiality rules rely too heavily on the ability of the relay operator to recognize and report crime. Because relay operators have little or no expertise in detecting crime, the error rate would be high and would include both the reporting of noncriminal conversations and failure to report criminal conversations. If all crimes were to be reported, overinclusive reporting would have the serious negative effect of subjecting innocent relay users to investigation. However, even if only felomies were to be reported, overmclusive reporting would result in police intrusion where felonies had not occurred. On the other hand, undermclusive relay operator errors would inadvertently protect criminals, thus weakening the rationale for adopting a limited confidentiality rule.

The relay operator error rate would also depend on the siniplicity of the limited confidentiality exception. A sinple rule would be easier to administer, thereby reducing the error rate. However, a confidentiality exception would probably require detailed rules defining what constituted a significant suspicion of criminal activity. For exainple, could a relay operator report a conversation that referred to selling "stuff"? Presumably not. What about "good stuff from Mendocino" or "some killer weed"? While a simple rule might allow a relay operator to report all these conversations and let the police or a inagistrate sort thein out, the

226. This would follow the title III rule as exemplified in United States v. Ross, 713 F.2d 389, 392 (8th Cir. 1983) (citing Roberts v. United States, 445 U.S. 552, 558 (1980), for the proposition that citizens have a "deeply rooted social obligation" to report felonies to the authorities).

227. This problem is not present when the operator discloses information after being subpoenaed. See infra notes 237.42 and accompanying text. 
inherent costs to relay users' privacy would outweigh any benefit. Such a rule also seems far from what Congress meant when it forbade "any" disclosure. Thus, a more complex rule would probably be necessary.

While himited confidentiality might discourage criminal use of the relay service, it would also discourage noncriminal use. Relay users would need to guard their conversations to avoid any possible misinterpretation by the relay operator. This would certainly reduce "marginal" conversations-ones that could be misinterpreted as criminal or that the relay user mistakenly believes are criminal. Moreover, a relay user might restrict her use of the relay for all private conversations were the system not absolutely confidential. Such self-censorship would inhibit the systen's ability to bring the hearing- and speech-mipaired into society.

Reduction in noncriminal relay use would depend on what limits on confidentiality were adopted and the relay user's perception of these limits. Highly publicized disclosures would lower confidence in the system's confidentiality. Likewise, complex rules governing disclosure of criminal conversations might cause users to misunderstand the rules and overreact by refraining from all private conversations. Moreover, a relay user's perception might be influenced by incoinplete information. An arrest based on a relay operator's disclosure might be highly publicized while the court's subsequent refusal to admit the intercepted evidence might not be so widely reported. Based on this incoinplete information, a relay user might forin an inaccurate opmion of the system's confidentiality. Therefore, in considering how to enforce section 225 , care should be taken to enhance the perception of confidentiality.

Another problem with a limited confidentiality interpretation of section 225 is the lack of judicial authority for such an approach. The other two alternatives-coinplete confidentiahty and no confidentiahty-might be justified as statutory interpretation. ${ }^{228}$ Drawing confidentiality lines based on the seriousness of the crime could have been a wise legislative choice, but it was not the approach of section 225 . Thus, the judiciary lacks the authority to adopt limited confidentiality as a rule.

The most coinpelling reason for adopting complete confidentiahty is to place liearing- and speech-impaired individuals on an equal footing with others. Allowing disclosure of criminal conversations will significantly increase the chance of police intrusion into the lives of relay users. To reduce that chance, relay users must curtail their communications. Even if relay users do that, they would still be subject to mistaken or malicious use of a relay operator's discretion to report a conversation to

228. No confidentiality for criminal conversations might be justified as a statutory interpretation because it adopts the background law, title III approach. See supra notes 157-90 and accompanying text. Complete confidentiality would be an implementation of the clear text of $\S 225$ prohibiting "any" disclosure. 
the police. A civil rights statute meant to end discrimination against individuals with disabilities should not be interpreted to create greater susceptibihity to police investigations.

\section{b. Cost to Law Enforcement of Complete Confidentiality}

Limited confidentiahity provides an alluring alternative to protecting criminals. After all, why should noncriminal users mind if only criminal relay use is outlawed? The resulting reduction in crime will benefit other relay users as well as the rest of society. However, noncriminal relay users bear a disproportionate cost in the loss of their privacy.

Furtherınore, allowing criminal relay conversations disclosure would not be an effective crime-fighting technique. First, few criminal conversations are likely to take place through the relay service regardless of confidentiality rules. A relay user would be unlikely to trust a coinplete confidentiality provision enough to plan a bank heist over the relay service. Thus, the number of criminals netted would be sinall. Second, allowing disclosure would not remove the ability to commit crime over the relay service. Prearranged code words could still allow users to plan or discuss a crime without detection. Third, relay operator testimony would be unreliable because section 225 prohibits keeping any record of any relay call. Moreover, a relay operator does not know the identities of the calling parties. And any given conversation may only hint at criminal activity. Criminal mforination would need to be coinpletely revealed in a single relay call in order to be useful. Finally, a relay operator's testimiony at trial would be limited by the hearsay rule. ${ }^{229}$

TDD users will not be shielded from law to a greater extent than regular telephone users. Voice telephone criminals may be cauglit by a legal wiretap or they may be unlucky enough to have a communications worker overhear and report their conversation. A TDD-equipped telephone line should also be subject to wiretaps and random service checks. Thus, "functional equivalency" would allow the police to wiretap a TDD telephone line in accordance with title III. Therefore, a nondisabled criminal would not enjoy any greater confidentiality by using the relay service.

In suminary, protection for criminal relay conversations appears to be the most reasonable interpretation of the statute. Confidentiality of all conversations regardless of their content is the simplest reading of the statute and the easiest rule to apply. Such a rule would provide hearing-

229. Out-of-court statements may not be offered to prove the truth of the matter asserted. FED. R. Evid. 801, 802. However, an out-of-court statement of a defendant that exposes her to criminal liability is admissible against her. FED. R. EvID. 801(d)(2)(a). This exception would allow relay operator testimony in any case in which the defendant had been the relay user. However, relay operator testimony would be of limited use against third parties because of the hearsay rule. 
and speech-impaired people with telecommunications privacy functionally equivalent to that enjoyed by others.

\section{B. How Should Conversations Be Protected?}

After concluding that criminal relay conversations should be protected, one nuust consider how that is to be accomphshed. The first and most important need is to prevent the operator froin disclosing conversations. I will reconimend that the FCC promulgate regulations that prevent such disclosures.

The role of the courts in coinpelling and using disclosures will also be considered. Unless a relay operator niay assert a privilege, the subpoena power of a court might force an operator to reveal a conversation. This Part will recommend adoption of such a privilege by FCC regulations or by court interpretation of section 225 . The final issue is what use a court should inake of relay conversations that have been disclosed. There, an exclusionary rule should apply to prevent the use of the testiinony and its fruits.

\section{Preventing Relay Operators from Disclosing Criminal Conversations}

Civil and criminal sanctions aganist the relay operator and the conimon carrier would prevent disclosure and guarantee the most confidentiality to relay users. There are four benefits to this approach. First, it allows the fewest outsiders access to any conversation. To the extent that a relay user suffers soine harm just from an outsider knowing the content of his private communications, regardless of how that knowledge is used, enforcing relay operator silence minimizes this harm.

Second, it resolves evidentiary problems that arise when the judiciary or law-enforcement officials receive notice of criminal conversations. ${ }^{230}$ If the relay operator is deterred by the threat of civil liability and remains silent, the courts and the police will never have an opportunity to use a conversation against a relay user. Thus, as a practical nratter, individual hability for relay operators under section 225 would keep most such conversations out of the courts.

Third, prohibiting relay operators from disclosing the content of conversations provides a bright-line rule that is easily understood by relay operators, relay users, and the police. A rule of no disclosure is the best rule for operators to apply because their lack of expertise in judging criminality could well result in overdisclosure to the police if they were called upon to reveal suspected criminal conversations. This simplicity will in turn imspire the greatest belief by the relay users that their conver-

230. This benefit occurs even if Congress did not intend to affect evidentiary rules in enacting $\S 225$. 
sational privacy is sacrosanct. Case by case exceptions to privacy are likely to reduce confidence in the system's confidentiality.

Finally, a rule of complete nondisclosure would provide a brightline rule for the courts as well. Courts would not be tempted to endorse a disclosure, even where a particularly unappealing defendant was involved, because the evidence would never be presented to them.

The FCC should adopt regulations establishing personal relay operator liability for disclosures. ${ }^{231}$ Section 225 gave the FCC the power to enforce section 225 agamst common carriers. ${ }^{232}$ Individual relay operators are common carriers under the definition in the Communications $\mathrm{Act}^{233}$ - the FCC may also direct penalties at them. Such penalties need not impose criminal sanctions to be effective. Requiring that relay operators lose their jobs in the event of disclosure would probably provide sufficient deterrence to disclosure. The penalties should be clearly set out in FCC regulations, however, so that relay operators will realize the consequences of breaching confidentiality and so that states will be bound to adopt the sanie rules in their intrastate systems certified under section 225.234

Without uniform FCC regulation, enforcing the confidentiality requirements could be coinphicated by the abihity of the states to obtain certification for authority over the intrastate relay network. ${ }^{235}$ Although the FCC retains authority to revoke a state's certification for failure to ineet minimum standards, ${ }^{236}$ the dispersion of enforcement authority among the states might lead to varying degrees of confidentiality protection.

\section{Subpoenas of Past Relay Conversations}

While preventimg voluntary disclosure of relay conversations serves the purposes of section 225, preventing compelled disclosure is inore problematic. Courts are generally free to compel relevant testimony through subpoena unless the testimony would be privileged. Thus, the question of the subpoena power is linked in part to the question of whether section 225 established an evidentiary privilege. ${ }^{237}$

Several arguments may be made for allowing a court to compel a relay operator's testimony through a subpoena. Allowing a court to sub.

231. The FCC proposed regulations do not specify penalties for violations of $\S 225$ 's confidentiality requirement. See 55 Fed. Reg. 50,037 (1990) (to be codified at 47 C.F.R. pts. 0, 32, $36,64, \& 69$ ) (proposed Dec. 4, 1990).

232. 47 U.S.C.A. $\S 225($ b)(2) (West 1991).

233. 47 U.S.C. $\S 153($ h) (1988).

234. State relay services certified by the FCC must meet or exceed the requirements of FCC regulations. 47 U.S.C.A. $§ 225(f)(2)(A)$ (West 1991).

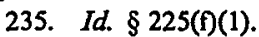

236. Id. $\S 225(\mathrm{f}(4)$.

237. See infra Part III.B.3. 
poena relay operators would have hittle impact on the number of conversations disclosed. Prohibiting voluntary relay operator disclosure to lawenforcement officials will usually prevent any subpoena from issumg because law enforcement is unlikely to have independent notice of any conversation's content. Since it would arise only infrequently, subpoenaed testimony might have hittle effect on relay users' perception of confidentiality. Thus, the benefits of full noncriminal use of the relay system might be realized without paying the price of protecting criminal activity. Furthermore, a magistrate would determine the relevance and potential criminality of a conversation rather than leaving these judgments to the less-skilled relay operator. The burden of the procedure would tend to limit its use to relatively clear instances of criminal conduct and the magistrate's participation would lower the incidence of errors.

However, stronger arguments may be made against allowing the subpoena of relay operators. First, because no comparable means of investigating the telephone conversations of hearing individuals exists, allowing relay operators to be subpoenaed would discriminate against hearing- and speech-impaired users. This would undermine section 225 's goal of providing functionally equivalent telecommurications access to the hearing and speech impaired. Allowing law-enforceinent officials more intrusive powers into the private lives of relay users should not be condoned.

Second, allowing subpoenaed disclosure might encourage relay operators to disclose conversations to the police anonymously in order to later reveal the conversation under subpoena. This would raise the number of revealed conversations, intruding more severely into the privacy of relay users.

Third, the unreliable nature of the evidence obtained through a subpoena would probably not justify the cost of reduced confidence in the relay system. Even were subpoenas used rather infrequently, such use might generate a good deal of publicity because the judicial machinery is invoked and the relay operator or the relay user might resist. Thus, even infrequent use could lower perceptions of confidentiality, resulting in more guarded conversations over the relay network. Moreover, several factors lower the chance of obtaining useful testimony througli a subpoena. These include large call volume, ${ }^{238}$ large number of operators, ${ }^{239}$ no records of calls, ${ }^{240}$ no callers identified, and possible operator resistance to cooperation. These factors will make it difficult for the police to

238. The California Relay Service already handles in excess of 8900 calls per day. California Relay Service Brochure, supra note 63.

239. Up to 120 relay operators may be on duty at a time. Id.

240. 47 U.S.C.A. $\$ 225$ (d)(1)(F) (West 1991). 
question a specific operator about specific relay calls and will make accurate recall of a relay conversation unlikely. Additionally, any testimony obtained might be excluded as hearsay. ${ }^{241}$ Given these limitations, the possibility of obtaining admissible evidence from a subpoena appears shight.

Finally, section 225 does not specifically authorize such an exception to its rule of nondisclosure. In contrast, section 605 explicitly authorizes a communications worker to disclose a conversation "in response to a subpoena issued by a court of competent jurisdiction, or on demand of other lawful authority."242 Because both section 225 and section 605 are part of the Communications Act of 1934, the omission of the subpoena authorization in section 225 could be interpreted as a deliberate attempt to specify greater protection for the relay system.

Overall, the balance of the argument favors prohibitmg a court from compellimg disclosure of a relay conversation. Little relevant evidence would be lost to such a ban and the enhanced privacy for relay users seems congruent with congressional intent.

\section{Preventing Evidentiary Use of Disclosed Conversations}

Banning the use of disclosed conversations as evidence would further make the relay service "functionally equivalent" to the voice telephone system. Just as title III authorized the exclusion of illegally intercepted evidence, a violation of section 225 should lead to exclusion of an illegally disclosed relay conversation.

Interpreting section 225 as both a privilege and an exclusionary rule best implements the broad phrasing that Congress chose in forbidding "any" disclosure. Because both privileges and exclusionary rules protect communications, Congress could choose either-or both. A privilege is necessary to allow a relay operator to refuse a subpoena. An exclusionary rule will further protect agamst disclosures by removing an incentive for the operator to anonymously disclose conversations to the police.

\section{a. Establishment of a Relay User Privilege}

Section 225 should be interpreted to establish an evidentiary privilege. A privilege is a logical choice: rules of privilege aim to protect commumications within certam relationships that society wishes to foster. ${ }^{243}$ Because the privilege protects the conversation of the relay users, either relay user should be able to invoke it to prevent the testimony of a relay operator. The relay operator should also be able to invoke the privilege to protect the privacy of the relay users.

241. See supra note 229.

242. 47 U.S.C. $\S 605(a)(5),(6)$ (1988).

243. See supra text accompanying notes 75-100. 
A uniform federal approach would protect the confidentiality of relay conversations best. States are free to grant an evidentiary privilege to relay users. One state has already done so. ${ }^{244}$ Several other states have broad confidentiality provisions similar to section $225 .{ }^{245}$ Conversely, however, states could deny a privilege, imperiling Congress' vision of a nationwide, uniform standard of TDD relay service and confidentiality. The harm of such an approach would be niagnified if relay users curtailed their conversations in uncertainty as to which approach a state would adopt.

Both the FCC and the courts can implement a uniform relay user privilege. FCC regulations should explicitly adopt a uniform privilege regulation in order to avoid patchwork confidentiality protection. ${ }^{246}$ States would need to adopt equivalent protection in order to certify their state relay systems. ${ }^{247}$ Federal courts should implement the privilege also. Privileges granted by an act of Congress are binding on federal courts. Federal Rule 501 states that privileges nray be created "by Act of Congress." ${ }^{248}$ These privileges apply in diversity cases.

A relay operator privilege should not have exceptions that allow the divulgence of certain criminal communications. As discussed above, the

244. A Connecticut statute provides that

[a]ny communication made by or to a deaf or hearing impaired person with the assistance of a person operating special telecommunications equipment capable of serving the needs of deaf or hearing impaired persons shall be deemed to be confidential and privileged and shall not be disclosed by such operator in any civil or criminal case or proceeding or in any legislative or administrative proceeding, unless the person making the confidential communication waives such privilege.

ConN. GEN. STAT. § 52-146m (1989).

245. See, e.g., ME. REv. STAT. ANN. tit. 35-A, § 8703(5) (West Supp. 1990) ("Relay service communications must be confidential."); MINN. STAT. ANN. § 237.54(2) (West Supp. 1991) ("The operator of the system shall keep all inessages confidential ....").

246. The National Center for Law and the Deaf has urged the FCC to adopt language similar to that of Conn. Gen. STAT. § 52-146m (1989). See National Center for Law and the Deaf, Comments: In the Matter of Telecornmunications Services for Hearing-Impaired and SpeechInpaired Individuals, and the Americans with Disabilities Act of 1990, CC Docket No. 90-571 at 34 n.37 (1991).

The FCC believes that all conversations, including criminal conversations, should be protected. The comments to the proposed regulations state that

[it] is the responsibility of the relay operator to repeat language or expressions that are either abhorrent to his or her sensibilities or convictions or are otherwise violative of state or federal law, e.g., those that are obscene or involve criminal activity that the operator would wish to report to authorities. Our view is that Congress has mandated that relay operators may not intentionally alter a relayed conversation, no matter what that conversation contains, or reveal its contents.

55 Fed. Reg. 50,037, 50,041 (1990) (proposed Dec. 4, 1990).

Unfortunately, the FCC's proposed regulations do not clearly set out this position, but instead use the broad language of $\S 225$. Id. at 50,046 (to be codified at 47 C.F.R. pt. 64.605 (d)(1)(vi)) (proposed Dec. 4, 1990).

247. 47 U.S.C.A. $\S 225(\mathfrak{f}(2)(\mathrm{A})$ (West 1991); see supra notes 23436 and accompanying text.

248. FED. R. EVID. 501. 
statute calls for complete confidentiality. ${ }^{249}$ Moreover, a comparison with other privileges supports complete confidentiality. The professional privileges, attorney-client and physician-patient, allow for disclosure in cases where the conversation did not occur im the context of seeking professional advice. ${ }^{250}$ In contrast, such exceptions do not apply when the principal rationale for the privilege is to foster a private relationship, such as in the husband-wife privilege. ${ }^{251}$ The privacy granted to TDD relay users is more akin to the latter privileges-it protects personal conversations regardless of whether professional advice is exchanged.

\section{b. Section 225 as a Statutory Exclusionary Rule}

Interpreting section 225 as a statutory exclusionary rule also offers protection for relay-user privacy. Inplymg an exclusionary rule from section 225 without explicit provision would be like the Supreme Court's action in the Nardone decisions. ${ }^{252}$ In Nardone $I$ the Court read the broad prohibition on communications disclosure within section 605 to include a prohibition on disclosure by a witness in federal court. ${ }^{253}$ The similarity of the broadly phrased prohibitions of section 225 and the then-current language of section 605 supports interpreting section 225 in light of the Nardone decisions. ${ }^{254}$ Moreover, Congress and the courts have previously used exclusionary rules to protect communication privacy. ${ }^{255}$ Thus, a section 225 exclusionary rule likely reflects what Congress nitended in enacting the provision.

\section{CONCLUSION}

The broad statutory language of section 225 should be given its full effect: protect the confidentiality of any relay conversation, regardless of its nature. Such protection would be "functionally equivalent" to the

249. See supra notes 51-55 and accompanying text.

250. See supra notes $96-97$ and accompanying text.

251. See supra note 98 and accompanying text.

252. See supra notes $134-48$ and accompanying text.

253. 302 U.S. 379, 383-84 (1937).

254. Section 225 "prohibit[s] relay operators from disclosing the content of any relayed conversation and from keeping records of the content of any such conversation beyond the duration of the call." 47 U.S.C.A. $\S 225(d)(1)(F)$ (West 1991). Before the 1968 amendments, section 605 provided that "no person ... shall intercept any communication and divulge or publish the existence, contents, substance, purport, effect or meaning of such intercepted communication to any person." Nardone v. United States (Nardone I), 302 U.S. 379, 381 (1937) (quoting 47 U.S.C. § 605 (1934) (current version at 47 U.S.C. $\$ 605$ (1988))).

255. See 18 U.S.C. $\$ 2515$ (1988) (exemplifying an explicit statutory exclusionary rule); see, e.g., Katz v. United States, 389 U.S. 347, 359 (1967) (overturning a conviction based on illegal evidence acquired in violation of the fourth amendment); Nardone I, 302 U.S. 379 (1937) (implying an exclusionary rule in $\S 605$ of the Communications Act of 1934); Nardone v. United States (Nardone II), 308 U.S. 338 (1939) (extending Nardone $I$ to "fruit of the poisonous tree"). 
privacy offered by the telecommunications system to all others. The Katz decision rejected a regime in which law-enforcement officials could monitor calls without warrants. ${ }^{256}$ Such a regime should also be rejected for section 225 relay users.

Both the FCC and the courts should play a role in implementing the confidentiality guarantees of section 225 . The FCC should promulgate regulations that (1) explicitly protect criminal conversations; (2) penalize common carriers and relay operators for breaches in confidentiality; and (3) give relay users a privilege to prevent relay operator testimony. The courts, even in the absence of FCC regulations, should exclude evidence obtained from TDD relay conversations. Such exclusion may be premised on interpreting section 225 as a congressionally established privilege, or as an implicit statutory exclusionary rule.

256. Katz, 389 U.S. at $354-59$. 
